\title{
VARIJABILNOST POPULACIJA DIVLJE TREŠNJE (Prunus avium L.) U SRBIJI PREMA MORFOLOŠKIM SVOJSTVIMA LISTOVA
}

\section{POPULATION VARIABILITY OF WILD CHERRY (Prunus avium L.) IN SERBIA ACCORDING TO THE LEAF MORPHOLOGY}

\author{
Vladan POPOVIĆ* ${ }^{*}$ Ivona KERKEZ**
}

\begin{abstract}
Sažetak
U radu je istraživana morfološka varijabilnost listova devet prirodnih populacija divlje trešnje (Prunus avium L.) na području Srbije. Na osnovi deset mjerenih morfoloških svojstava listova i jednog izvedenog omjera utvrđena je unutarpopulacijska i međupopulacijska varijabilnost. $U$ istraživanju su korištene deskriptivne i multivarijantne statističke metode. Rezultati istraživanja ukazuju na visoku varijabilnost istraživanih populacija, kao i na to da se populacije međusobno statistički značajno razlikuju po svim istraživanim svojstvima. Unutarpopulacijska varijabilnost veća je od međupopulacijske varijabilnosti. Prema klasterskoj analizi istraživane populacije se grupiraju na način prema kojem nisu geografski logično raspoređene. Populacije Boranja i Fruška Gora se nalaze na većoj udaljenosti od ostalih istraživanih populacija.
\end{abstract}

KLJUČNE RIJEČI: Prunus avium L., morfologija lista, varijabilnost, populacija.

\section{UVOD}

\section{INTRODUCTION}

Divlja trešnja (Prunus avium L.) je najznačajnija vrsta drveća iz familije Rosaceae u Europi. Vrlo je vrijedna šumska vrsta koja raste u mješovitim šumama u Europi, zapadnoj Aziji i na krajnjem severu Afrike. Na području Europe divlja trešnja nije ugrožena vrsta. Međutim, genetička raznolikost njezinih populacija je ugrožena od niza čimbenika: sječa i uništavanje staništa, prijenos sjemena iz područja s različitim ekološkim uvjetima, prikupljanje sjemena iz malih populacija, hibridizacija sa sortama trešnje, štetočine i bolesti. Općenito prijetnje uključuju krčenje šuma, zagađenje okoliša i klimatske promijene (Russell 2003). Brzorastuća je vrsta koja uglavnom raste na osami i šumskim rubovima, a rjeđe se javlja u gustim mješovitim sastojinama (Santi i sur.
1998). Divlja trešnja je značajna i iz ekonomskih i ekoloških razloga. Drvo divlje trešnje je cijenjeno u industriji namještaja kao zamjena za mahagonij. Zbog dekorativnih, medonosnih i ljekovitih svojstava te jestivih plodova pogodna je za podizanje poljezaštitnih pojaseva i drvoreda, a pogodna je i za osnivanje šumskih kultura na napuštenim poljoprivrednim površinama, livadama, vinogradima i voćnjacima (Ballian 2000; Tančeva Crmarić i sur. 2006; Mikić 2007). „Drvetom budućnosti“ proglašena je još 1954. godine (Bejdl 1954), ali se u Europi nije dovoljno vodilo računa o njoj kao vrlo bitnoj vrsti u šumskim ekosustavima. Kao šumska voćkarica značajna je i kao predak mnogim sortama i hibridima te kao podloga za kalemljenje.

Osnovu za upoznavanje adaptivnog i genetičkog potencijala divlje trešnje na nekom području predstavljaju istraživanja populacijske strukture i genetičke varijabilnosti na

\footnotetext{
* Dr. sc. Vladan Popović, Institut za šumarstvo, Kneza Višeslava 3, 11000 Beograd, Republika Srbija, vladanpop79@gmail.com

** Ivona Kerkez, MSc student, Univerzitet u Beogradu, Šumarski fakultet, Kneza Višeslava 1, 11000 Beograd, Republika Srbija
} 


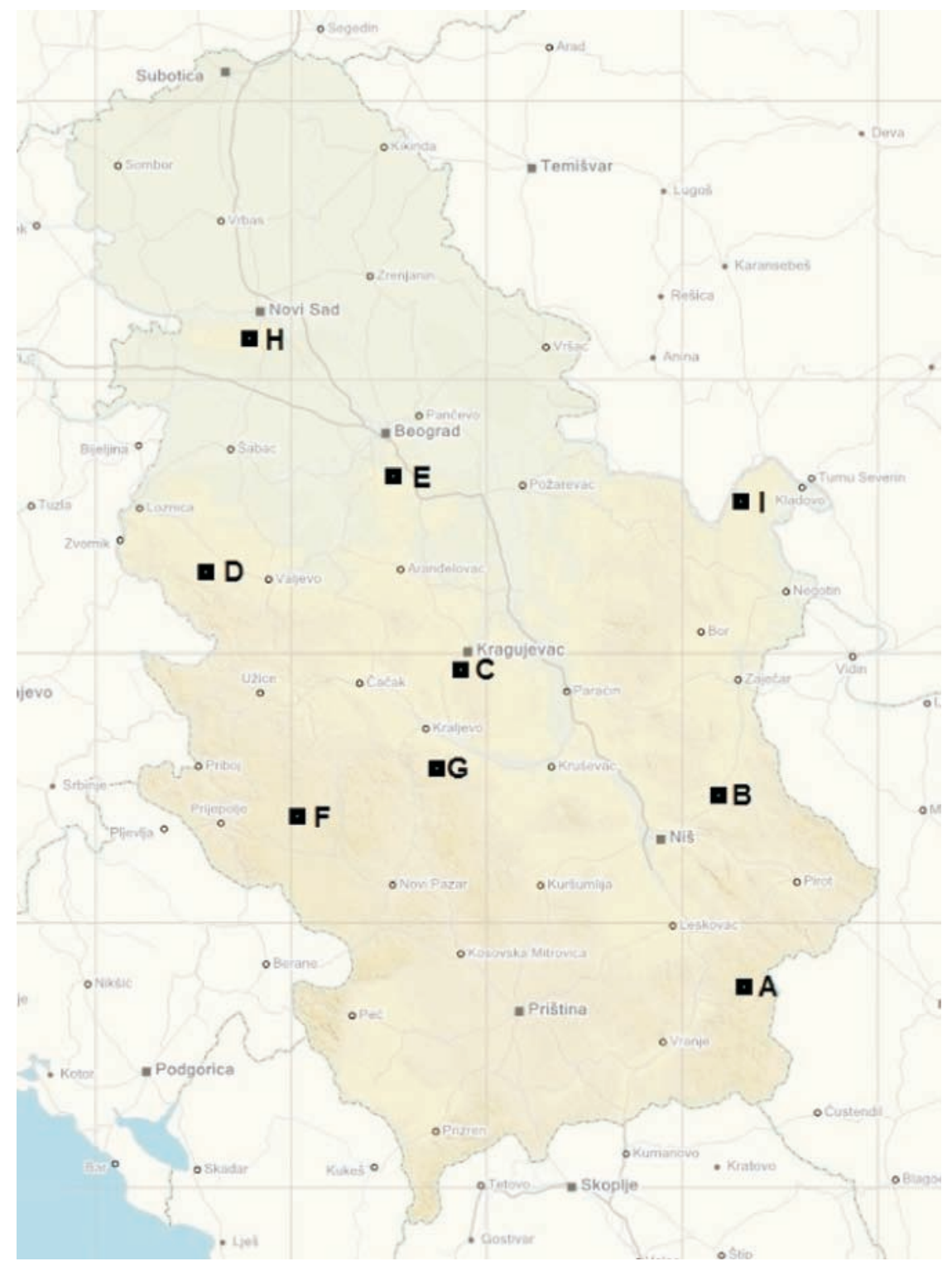

Slika 1: Karta prostornog rasporeda istraživanih populacija (A - Vlasina, B - Tresibaba, C - Šumarice, D-Boranja, E-Lipovica, F - Javor, G - Goč, H - Fruška Gora, I Đerdap).

Figure 1. Map of spatial distribution of the studied populations (A - Vlasina, B - Tresibaba, C Sumarice, D - Boranja, E - Lipovica, F - Javor, $\mathrm{G}$ - Goč, H - Fruška Gora, I - Đerdap). razini genotipova i/ili populacija. Sveobuhvatna istraživanja na području čitavog areala vrste još uvijek nisu provedena, a dosadašnja istraživanja provedena su uglavnom na regionalnoj razini (Santi i Lemoine 1990; Weiser 1996; MeierDinkel i sur. 1997; Kleinschmit i sur. 1999; Ballian 2000; Kleinschmit i sur. 2003; Russel 2003; Mikić i sur. 2004; Kitin i sur. 2005; Tančeva Crmarić i sur. 2006; Mikić 2007; Ballian i Čabaravdić 2007; Nonić i sur. 2013). Navedenim istraživanjima utvrđena je značajna raznolikost morfoloških i fenoloških svojstava divlje trešnje.

Opsežna istraživanja su provedena u svrhu utvrđivanja genetičkih odnosa između sorata i prirodnih populacija trešnje (Guarino i sur. 2009; Jing-Yong i sur. 2009), kao i za genotipizaciju njezinih kutivara (Gerlach i Stosser 1998; Boritzki i sur. 2000; Aradhya i sur. 2004; Ducci i Santi 2004; Turkec i sur. 2005). Detaljna istraživanja koja su obuhvatila ekologiju, genetiku, selekciju, podizanje klonskih nasada, osnivanje klonskih plantaža i konzervaciju divlje trešnje napravljena su u Italiji (Ducci i Santi 1997; Ducci 2005).

Očuvanje biodiverziteta je civilizacijski zadatak suvremenog čovjeka i društva. U cilju harmoničnog odnosa čovjeka i prirode neophodno je uskladiti očuvanje biološke raznolikosti i njegovo korištenje. S obzirom da su ekosustavi i biodiverzitet Zemlje degradirani i izmijenjeni u velikoj mjeri, uspjeh bi bio kada bi se održali vitalni elementi biodiverziteta, tj. umjerenim korištenjem sačuvali od daljnjeg propadanja. Pod pojmom očuvanje biodiverziteta podrazumijeva se pokušaj očuvanja evolucijske raznolikosti živog svijeta planeta, dok se unutar koncepta zaštite prirode podrazumijevaju konkretni oblici zaštite ekološki vrednijih dijelova prirode. Očuvanje biodiverziteta obuhvaća kontrolirano i održivo korištenje genskih resursa, obnavljanje narušenih ekosustava, prirodnih staništa i degradiranih predjela i trajnu zaštitu prirodnih vrijednosti. 
Vitalnost i opstanak populacija drvenastih vrsta u izmijenjenim uvjetima sredine ovisi o zadovoljavajućem stupanju njihove genetičke varijabilnosti kao osnova za adaptaciju i nesmetanu evoluciju (Šijačić-Nikolić i Milovanović 2012). U šumskom fondu Srbije divlja trešnja spada u kategoriju vrsta koje su pod rizikom (Banković i sur. 2009) i kojima se ne posvećuje dovoljno pažnje. Kako bi se osiguralo očuvanje genofonda divlje trešnje i provelo kvalitetno upravljanje genskim resursima, neophodna su detaljna istraživanja populacijske strukture i genetičke raznolikosti.

U radu je istražena unutarpopulacijska i međupopulacijska varijabilnost divlje trešnje u devet prirodnih populacija u Srbiji na osnovi morfoloških obilježja listova, pri čemu su korištene deskriptivne i multivarijatne statističke metode. Rezultati dobiveni u ovom istraživanju mogu se koristiti u daljnjem oplemenjivanju vrste, kao i za očuvanje genofonda.

\section{MATERIJAL I METODE}

\section{MATERIAL AND METHODS}

Materijal za istraživanje sakupljen je u devet prirodnih populacija divlje trešnje u Srbiji (Slika 1). Sabrani su listovi s deset stabala po populaciji, dok je svako stablo bilo pred-

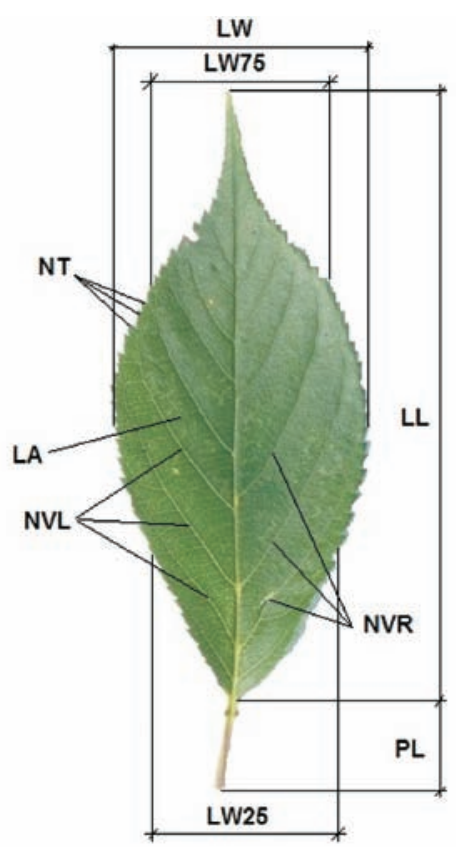

Slika 2. Mjerena svojstva listova: LA-površina plojke; LW-širina plojke na najširem dijelu plojke; LW25-širina plojke na $25 \%$ duljine plojke; LW75-širina plojke na 75 \% duljine plojke; LL-duljina plojke; PL-duljina peteljke; NT-broj zubaca; NVL-broj bočnih žila na lijevoj strani plojke; NVR-broj bočnih žila na desnoj strani plojke.

Figure 2. Measured leaf traits: LA-leaf blade area; LW-lamina width at the widest point; LW25-lamina width at $25 \%$ of lamina length; LW75-lamina width at $75 \%$ of lamina length; LL-lamina length; PL-petiole length; NTnumber of teeth; NVL-number of veins on the left side of the leaf; NVRnumber of veins on the right side of the leaf. stavljeno sa po 50 zdravih i neoštećenih te u potpunosti razvijenih listova. Uzorkovana su isključivo fiziološki zrela stabla koja su plodonosila. Listovi su sakupljani s kratkih fertilnih izbojaka s rubnih stabala ili sa stabala na osami, i to iz vanjskog osvijetljenog dijela krošnje (Tucović 1965; Franjić 1996; Kajba 1996; Idžojtić 2006; Mikić 2007; Ballian i sur. 2010; Zebec i sur. 2010) tijekom kolovoza 2014. godine.

Uzorkovani listovi su herbarizirani i naknadno analizirani. Nakon skeniranja, lišće je izmjereno LAMINA softverskim alatom (Bylesjö i sur. 2008). Izbor mjerenih morfoloških svojstava je usklađen s istraživanjima Mikić (2007). Točnost mjerenja iznosila je $0,1 \mathrm{~mm}$. Ukupno je izmjereno devet svojstava: LA-površina plojke $\left(\mathrm{cm}^{2}\right)$; LPE-opseg plojke $(\mathrm{cm})$; LW-širina plojke na najširem dijelu plojke $(\mathrm{mm})$; LW25-širina plojke na $25 \%$ duljine plojke (mm); LW75širina plojke na $75 \%$ duljine plojke (mm); LL-duljina plojke (mm); PL-duljina peteljke (mm); NT-broj zubaca; NVLbroj bočnih žila na lijevoj strani plojke; NVR-broj bočnih žila na desnoj strani plojke (Slika 2). Nakon izmjere, mjerene varijable duljina i širina plojke stavljene su u međusobni odnos (LL/LW).

Morfološka svojstva listova opisana su putem deskriptivnih statističkih pokazatelja: aritmetička sredina (x), standardna devijacija (SD), koeficijent varijabilnosti (CV \%). U svrhu utvrđivanja unutarpopulacijske i međupopulacijske varijabilnosti korištena je univarijatna analiza varijance (ANOVA). Analizirani faktori varijabilnosti bili su populacija i stablo, stim da je faktor stablo ugniježđen unutar faktora populacija. REML metoda (Restricted Maximum Likelihood Method) je korištena kako bi se dobio uvid u zastupljenost pojedinih istraživanih izvora varijabilnosti u ukupnoj varijanci (unutar stabla, između stabala unutar populacije, između populacija). Ukoliko su između populacija postojale statistički značajne razlike u vrijednostima aritmetičkih sredina za promatrana svojstva, provedeno je i dodatno testiranje Fisherovim multiplim testovima (LSD) za sve parove populacija sa ciljem utvrđivanja koje se točno populacije međusobno statistički značajno razlikuju. Kako bi se utvrdili odnosi između istraživanih populacija korištena je klasterska analiza. Dendrogram je baziran na Euklidskim udaljenostima primjenom UPGMA metode (Unweighted Pair Group Average Method). U multivarijantnim statističkim metodama korišteni su originalni podaci. Sve navedene statističke analize provedene su pomoću statističkog programa STATISTICA 7.0 (StatSoft Inc. 2004).

\section{REZULTATI} RESULTS

U tablici 1 prikazani su rezultati deskriptivne statističke analize. Prosječno najvećom površinom plojke odlikovala se populacija Boranja $\left(51,48 \mathrm{~cm}^{2}\right)$, a najmanjom populacija Javor $\left(29,76 \mathrm{~cm}^{2}\right)$. Prosječne vrijednosti opsega plojke kreću 
Tablica 1. Deskriptivna statistika za mjerena morfološka svojstva listova.

Table 1. Descriptive statistics of the studied leaf characteristics.

\begin{tabular}{|c|c|c|c|c|c|c|c|c|c|c|c|c|}
\hline \multirow{2}{*}{$\begin{array}{l}\text { Deskriptivni } \\
\text { Pokazatelji / } \\
\text { Descriptive } \\
\text { parameters }\end{array}$} & \multirow{2}{*}{$\begin{array}{l}\text { Populacija / } \\
\text { Population }\end{array}$} & \multicolumn{11}{|c|}{ Svojstvo / Trait } \\
\hline & & LA & LPE & LW & LW25 & LW75 & LL & LL/LW & $\mathrm{PL}$ & NT & NVL & NVR \\
\hline \multirow{10}{*}{$\mathrm{x}$} & $A$ & 32,33 & 23,53 & 47,79 & 30,52 & 40,00 & 97,11 & 2,05 & 27,47 & 71,13 & 14,33 & 14,39 \\
\hline & B & 30,51 & 22,59 & 48,86 & 34,30 & 40,12 & 89,04 & 1,83 & 24,37 & 65,58 & 12,99 & 13,08 \\
\hline & C & 37,33 & 23,00 & 56,19 & 41,76 & 45,71 & 93,73 & 1,67 & 26,07 & 76,04 & 12,93 & 13,01 \\
\hline & D & 51,48 & 29,35 & 64,69 & 38,19 & 57,05 & 115,68 & 1,81 & 25,08 & 58,77 & 13,29 & 13,01 \\
\hline & $E$ & 30,96 & 21,10 & 50,36 & 37,16 & 41,15 & 86,17 & 1,72 & 31,43 & 69,16 & 12,58 & 12,54 \\
\hline & $\mathrm{F}$ & 29,76 & 22,65 & 48,51 & 33,28 & 39,38 & 89,68 & 1,87 & 22,45 & 63,06 & 13,27 & 13,24 \\
\hline & G & 34,26 & 22,12 & 55,73 & 41,32 & 45,75 & 86,89 & 1,56 & 29,93 & 68,88 & 12,51 & 12,64 \\
\hline & $\mathrm{H}$ & 35,75 & 24,08 & 53,20 & 41,31 & 42,13 & 94,19 & 1,79 & 28,00 & 62,44 & 12,54 & 12,59 \\
\hline & I & 33,76 & 22,61 & 52,93 & 40,82 & 41,04 & 89,76 & 1,69 & 38,29 & 78,84 & 12,69 & 12,81 \\
\hline & mean & 35,13 & 23,45 & 53,14 & 37,63 & 43,59 & 93,58 & 1,78 & 28,12 & 68,21 & 13,02 & 13,03 \\
\hline \multirow{10}{*}{ SD } & A & 12,34 & 5,34 & 9,63 & 10,65 & 9,16 & 21,39 & 0,34 & 7,22 & 8,56 & 2,54 & 2,56 \\
\hline & B & 10,69 & 4,78 & 8,67 & 8,15 & 8,12 & 18,94 & 0,28 & 6,51 & 11,95 & 1,76 & 1,78 \\
\hline & C & 11,21 & 4,11 & 8,46 & 8,62 & 7,50 & 17,27 & 0,23 & 5,47 & 10,41 & 1,71 & 1,66 \\
\hline & D & 15,61 & 4,95 & 11,82 & 9,43 & 11,05 & 18,05 & 0,22 & 5,46 & 12,07 & 1,73 & 1,70 \\
\hline & $\mathrm{E}$ & 10,70 & 4,14 & 8,62 & 8,07 & 7,67 & 17,50 & 0,24 & 6,66 & 6,25 & 1,57 & 1,60 \\
\hline & $\mathrm{F}$ & 8,88 & 4,06 & 7,61 & 9,74 & 6,75 & 17,16 & 0,34 & 6,38 & 6,67 & 1,72 & 1,78 \\
\hline & G & 11,43 & 4,35 & 9,75 & 8,68 & 8,77 & 16,18 & 0,17 & 7,19 & 6,84 & 1,52 & 1,56 \\
\hline & $\mathrm{H}$ & 9,64 & 3,83 & 7,79 & 8,91 & 7,20 & 16,42 & 0,31 & 5,43 & 9,62 & 1,83 & 1,86 \\
\hline & I & 12,78 & 5,64 & 8,76 & 8,52 & 8,22 & 21,95 & 0,28 & 13,03 & 10,35 & 1,85 & 1,82 \\
\hline & mean & 11,48 & 4,58 & 9,01 & 8,97 & 8,27 & 18,32 & 0,27 & 7,04 & 9,19 & 1,80 & 1,81 \\
\hline \multirow{10}{*}{ CV (\%) } & A & 38,18 & 22,71 & 20,16 & 34,90 & 22,89 & 22,03 & 16,59 & 26,28 & 12,04 & 17,73 & 17,77 \\
\hline & B & 35,05 & 21,16 & 17,74 & 23,75 & 20,24 & 21,27 & 15,35 & 26,70 & 18,22 & 13,56 & 13,60 \\
\hline & C & 30,04 & 17,87 & 15,05 & 20,63 & 16,41 & 18,42 & 13,69 & 20,97 & 13,70 & 13,19 & 12,79 \\
\hline & $D$ & 30,33 & 16,85 & 18,27 & 24,68 & 19,37 & 15,60 & 12,32 & 21,79 & 20,53 & 13,00 & 13,10 \\
\hline & $\mathrm{E}$ & 34,55 & 19,62 & 17,11 & 21,72 & 18,64 & 20,31 & 13,72 & 21,20 & 9,04 & 12,50 & 12,79 \\
\hline & $\mathrm{F}$ & 29,84 & 17,92 & 15,68 & 29,27 & 17,14 & 19,14 & 17,95 & 28,43 & 10,58 & 12,95 & 13,46 \\
\hline & G & 33,38 & 19,68 & 17,49 & 21,00 & 19,16 & 18,63 & 10,59 & 24,01 & 9,93 & 12,14 & 12,36 \\
\hline & $\mathrm{H}$ & 26,96 & 15,89 & 14,64 & 21,57 & 17,09 & 17,43 & 17,27 & 19,39 & 15,41 & 14,60 & 14,77 \\
\hline & I & 37,84 & 24,93 & 16,55 & 20,87 & 20,03 & 24,45 & 16,44 & 34,05 & 13,12 & 14,56 & 14,21 \\
\hline & mean & 32,91 & 19,63 & 16,96 & 24,27 & 19,00 & 19,70 & 14,88 & 24,76 & 13,62 & 13,80 & 13,87 \\
\hline
\end{tabular}

se od 21,1 cm (populacija Lipovica) do 29,35 cm (populacija Boranja). Populacija Boranja se izdvaja s najvećim prosječnim vrijednostima za širinu plojke ( $\mathrm{LW}=64,69$ $\mathrm{mm}$ ), širinu plojke na $75 \%$ duljine plojke (LW75 = 57,05 $\mathrm{mm})$ i duljinu plojke $(\mathrm{LL}=115,68 \mathrm{~mm})$. Najniže prosječne vrijednosti za širinu plojke $(\mathrm{LW}=47,79 \mathrm{~mm})$ i širinu plojke na $25 \%$ duljine (LW25 = 30,52 mm) zabilježene su kod populacije Vlasina. Najniža prosječna vrijednost širine plojke na $75 \%$ duljine (LW75 = 39,38 mm) utvrđena je kod populacije Javor, a duljine plojke $(\mathrm{LL}=86,17 \mathrm{~mm})$ kod populacije Lipovica. Populacija Vlasina se izdvaja s najvišim prosječnim vrijednostima za sljedeća svojsta: odnos duljine i širine plojke $(L L / L W=2,05)$, broj bočnih žila na lijevoj strani plojke $(\mathrm{NVL}=14,33)$ i broj bočnih žila na desnoj strani plojke (NVR $=14,39)$. Najniža prosječna vrijednost za odnos duljine i širine plojke $(\mathrm{LL} / \mathrm{LW}=1,56)$ i broj bočnih žila na lijevoj strani plojke (NVL $=12,51)$ utvrđena je kod populacije Goč, a broj bočnih žila na desnoj strani plojke (NVR $=12,54)$ kod populacije Lipovica. Populacija Đerdap se ističe sa najvišim prosječnim vrijednostima za duljinu peteljke $(\mathrm{PL}=38,29 \mathrm{~mm})$ i broj zubaca $(\mathrm{NT}=$ $78,84)$. Prosječno najkraće peteljke imala je populacija Javor $(\mathrm{PL}=22,45 \mathrm{~mm})$, a prosječno najmanji broj zubaca (NT $=58,77)$ populacija Boranja. 
Tabela 2. Rezultati univarijantne analize varijance (ANOVA).

Table 2. Results of univariate analysis of variance (ANOVA).

\begin{tabular}{|c|c|c|c|c|c|c|c|c|c|c|}
\hline \multirow{2}{*}{$\begin{array}{l}\text { Svojstvo / } \\
\text { Trait }\end{array}$} & \multicolumn{9}{|c|}{ Unutar populacija/Within populations } & \multirow{2}{*}{$\begin{array}{l}\text { Između populacija / } \\
\text { Between populations }\end{array}$} \\
\hline & $A$ & B & $\mathrm{C}$ & $\mathrm{D}$ & $E$ & $\bar{F}$ & $\bar{G}$ & $\mathrm{H}$ & 1 & \\
\hline LA & $p<0,01$ & $\mathrm{p}<0,01$ & $p<0,01$ & $\mathrm{p}<0,01$ & $p<0,01$ & $p<0,01$ & $\mathrm{p}<0,01$ & $p<0,01$ & $p<0,01$ & $p<0,01$ \\
\hline LPE & $p<0,01$ & $p<0,01$ & $p<0,01$ & $p<0,01$ & $p<0,01$ & $p<0,01$ & $p<0,01$ & $p<0,01$ & $p<0,01$ & $p<0,01$ \\
\hline LW & $\mathrm{p}<0,01$ & $p<0,01$ & $p<0,01$ & $\mathrm{p}<0,01$ & $p<0,01$ & $p<0,01$ & $\mathrm{p}<0,01$ & $p<0,01$ & $p<0,01$ & $p<0,01$ \\
\hline LW25 & $p<0,01$ & $p<0,01$ & $p<0,01$ & $p<0,01$ & $p<0,01$ & $p<0,01$ & $\mathrm{p}<0,01$ & $p<0,01$ & $p<0,01$ & $p<0,01$ \\
\hline LW75 & $\mathrm{p}<0,01$ & $p<0,01$ & $p<0,01$ & $\mathrm{p}<0,01$ & $p<0,01$ & $p<0,01$ & $\mathrm{p}<0,01$ & $p<0,01$ & $p<0,01$ & $p<0,01$ \\
\hline LL & $\mathrm{p}<0,01$ & $\mathrm{p}<0,01$ & $p<0,01$ & $\mathrm{p}<0,01$ & $p<0,01$ & $p<0,01$ & $\mathrm{p}<0,01$ & $p<0,01$ & $p<0,01$ & $p<0,01$ \\
\hline LL/LW & $\mathrm{p}<0,01$ & $\mathrm{p}<0,01$ & $\mathrm{p}<0,01$ & $\mathrm{p}<0,01$ & $p<0,01$ & $\mathrm{p}<0,01$ & $p<0,01$ & $p<0,01$ & $p<0,01$ & $p<0,01$ \\
\hline $\mathrm{PL}$ & $\mathrm{p}<0,01$ & $\mathrm{p}<0,01$ & $\mathrm{p}<0,01$ & $\mathrm{p}<0,01$ & $p<0,01$ & $\mathrm{p}<0,01$ & $\mathrm{p}<0,01$ & $p<0,01$ & $p<0,01$ & $p<0,01$ \\
\hline NT & $\mathrm{p}<0,01$ & $p<0,01$ & $p<0,01$ & $\mathrm{p}<0,01$ & $p<0,01$ & $p<0,01$ & $p<0,01$ & $p<0,01$ & $p<0,01$ & $p<0,01$ \\
\hline NVL & $\mathrm{p}<0,01$ & $\mathrm{p}<0,01$ & $\mathrm{p}<0,01$ & $\mathrm{p}<0,01$ & $p<0,01$ & $\mathrm{p}<0,01$ & $\mathrm{p}<0,01$ & $p<0,01$ & $\mathrm{p}<0,01$ & $p<0,01$ \\
\hline NVR & $\mathrm{p}<0,01$ & $\mathrm{p}<0,01$ & $p<0,01$ & $\mathrm{p}<0,01$ & $p<0,01$ & $p<0,01$ & $\mathrm{p}<0,01$ & $p<0,01$ & $p<0,01$ & $p<0,01$ \\
\hline
\end{tabular}

Tablica 3. Rezultati komparacije parova populacija.

Table 3. Results of populations pairwise comparisons.

\begin{tabular}{|c|c|c|c|c|c|c|c|c|c|c|c|}
\hline \multirow{2}{*}{$\begin{array}{l}\text { Komparacija populacija / } \\
\text { Comparison of populations }\end{array}$} & \multicolumn{11}{|c|}{ Svojstvo / Trait } \\
\hline & LA & LPE & LW & LW25 & LW75 & LL & LL/LW & $\mathrm{PL}$ & NT & NVL & NVR \\
\hline$A-B$ & $p<0,05$ & $p<0,01$ & 0,07 & $\mathrm{p}<0,01$ & 0,72 & $\mathrm{p}<0,01$ & $p<0,01$ & $p<0,01$ & $p<0,01$ & $p<0,01$ & $p<0,01$ \\
\hline$A-C$ & $\mathrm{p}<0,01$ & 0,12 & $p<0,01$ & $\mathrm{p}<0,01$ & $p<0,01$ & 0,32 & $p<0,01$ & 0,07 & $p<0,01$ & $p<0,05$ & $p<0,05$ \\
\hline$A-D$ & $p<0,01$ & $p<0,01$ & $p<0,01$ & $\mathrm{p}<0,01$ & $p<0,01$ & $p<0,01$ & $p<0,01$ & $p<0,01$ & $p<0,01$ & $p<0,01$ & $p<0,01$ \\
\hline$A-E$ & 0,09 & $p<0,01$ & $p<0,05$ & $p<0,01$ & 0,21 & $p<0,01$ & $p<0,01$ & $p<0,01$ & $p<0,01$ & $p<0,01$ & $p<0,01$ \\
\hline$A-F$ & $p<0,01$ & $p<0,05$ & 0,35 & $\mathrm{p}<0,05$ & 0,09 & $p<0,01$ & $p<0,01$ & $p<0,01$ & $p<0,01$ & $p<0,01$ & $p<0,01$ \\
\hline$A-G$ & $p<0,05$ & 0,11 & $\mathrm{p}<0,01$ & $\mathrm{p}<0,01$ & $p<0,01$ & $\mathrm{p}<0,01$ & $p<0,01$ & $p<0,01$ & $\mathrm{p}<0,01$ & $\mathrm{p}<0,01$ & $p<0,01$ \\
\hline $\mathrm{A}-\mathrm{H}$ & $p<0,01$ & 0,07 & $p<0,01$ & $p<0,01$ & $p<0,05$ & 0,13 & $p<0,01$ & 0,09 & $p<0,01$ & $p<0,01$ & $p<0,01$ \\
\hline$A-I$ & 0,11 & 0,08 & $p<0,01$ & $p<0,01$ & 0,06 & $\mathrm{p}<0,01$ & $\mathrm{p}<0,01$ & $p<0,01$ & $p<0,01$ & $\mathrm{p}<0,01$ & $p<0,01$ \\
\hline$B-C$ & $\mathrm{p}<0,01$ & 0,06 & $p<0,01$ & $\mathrm{p}<0,01$ & $p<0,01$ & $p<0,05$ & 0,08 & $p<0,01$ & $p<0,01$ & 0,13 & 0,12 \\
\hline$B-D$ & $p<0,01$ & $p<0,01$ & $\mathrm{p}<0,01$ & $p<0,01$ & $p<0,01$ & $\mathrm{p}<0,01$ & 0,65 & $p<0,01$ & $p<0,01$ & 0,31 & 0,26 \\
\hline$B-E$ & 0,21 & $\mathrm{p}<0,05$ & 0,09 & $\mathrm{p}<0,01$ & 0,10 & 0,38 & $\mathrm{p}<0,01$ & $\mathrm{p}<0,01$ & $p<0,01$ & 0,13 & $p<0,01$ \\
\hline$B-F$ & 0,13 & 0,18 & 0,22 & 0,68 & 0,09 & 0,31 & 0,12 & $\mathrm{p}<0,01$ & $p<0,01$ & 0,07 & 0,07 \\
\hline$B-G$ & $p<0,01$ & 0,35 & $\mathrm{p}<0,01$ & $p<0,01$ & $p<0,01$ & 0,22 & $\mathrm{p}<0,01$ & $p<0,01$ & $p<0,01$ & $p<0,05$ & $p<0,01$ \\
\hline $\mathrm{B}-\mathrm{H}$ & $p<0,01$ & $\mathrm{p}<0,01$ & $p<0,01$ & $\mathrm{p}<0,01$ & $p<0,05$ & $p<0,01$ & $\mathrm{p}<0,05$ & $p<0,01$ & $\mathrm{p}<0,01$ & $\mathrm{p}<0,05$ & $p<0,05$ \\
\hline$B-1$ & $\mathrm{p}<0,01$ & 0,15 & $\mathrm{p}<0,01$ & $\mathrm{p}<0,01$ & 0,11 & 0,48 & $\mathrm{p}<0,05$ & $\mathrm{p}<0,01$ & $\mathrm{p}<0,01$ & 0,07 & 0,08 \\
\hline$C-D$ & $\mathrm{p}<0,01$ & $\mathrm{p}<0,01$ & $\mathrm{p}<0,01$ & $p<0,05$ & $p<0,05$ & $p<0,01$ & $\mathrm{p}<0,01$ & 0,15 & $\mathrm{p}<0,01$ & 0,09 & 0,15 \\
\hline$C-E$ & $p<0,01$ & $p<0,05$ & $p<0,01$ & $p<0,01$ & $p<0,01$ & $p<0,05$ & 0,23 & $p<0,01$ & $p<0,01$ & 0,09 & $p<0,05$ \\
\hline$C-F$ & $\mathrm{p}<0,01$ & 0,21 & $\mathrm{p}<0,01$ & $p<0,01$ & $p<0,01$ & $p<0,01$ & $\mathrm{p}<0,01$ & $p<0,01$ & $\mathrm{p}<0,01$ & 0,06 & 0,09 \\
\hline$C-G$ & $\mathrm{p}<0,01$ & 0,09 & 0,24 & 0,35 & 0,68 & $\mathrm{p}<0,01$ & $\mathrm{p}<0,05$ & $\mathrm{p}<0,01$ & $\mathrm{p}<0,01$ & $\mathrm{p}<0,05$ & $p<0,05$ \\
\hline $\mathrm{C}-\mathrm{H}$ & $\mathrm{p}<0,05$ & $\mathrm{p}<0,01$ & $p<0,01$ & 0,35 & $p<0,05$ & 0,57 & $\mathrm{p}<0,01$ & $p<0,01$ & $p<0,01$ & $p<0,05$ & $p<0,05$ \\
\hline$C-1$ & $\mathrm{p}<0,01$ & $p<0,01$ & $\mathrm{p}<0,01$ & 0,44 & $p<0,05$ & $p<0,05$ & 0,72 & $p<0,01$ & $\mathrm{p}<0,01$ & 0,08 & 0,09 \\
\hline$D-E$ & $\mathrm{p}<0,01$ & $\mathrm{p}<0,01$ & $\mathrm{p}<0,01$ & 0,23 & $p<0,01$ & $\mathrm{p}<0,01$ & $\mathrm{p}<0,01$ & $p<0,01$ & $\mathrm{p}<0,01$ & $\mathrm{p}<0,01$ & $p<0,05$ \\
\hline$D-F$ & $\mathrm{p}<0,01$ & $p<0,01$ & $p<0,01$ & $\mathrm{p}<0,01$ & $p<0,01$ & $\mathrm{p}<0,01$ & 0,07 & $p<0,01$ & $\mathrm{p}<0,01$ & 0,18 & 0,15 \\
\hline$D-G$ & $\mathrm{p}<0,01$ & $\mathrm{p}<0,01$ & $\mathrm{p}<0,01$ & $p<0,01$ & $p<0,01$ & $p<0,01$ & $\mathrm{p}<0,01$ & $p<0,01$ & $\mathrm{p}<0,01$ & $\mathrm{p}<0,01$ & $p<0,01$ \\
\hline $\mathrm{D}-\mathrm{H}$ & $\mathrm{p}<0,01$ & $p<0,01$ & $\mathrm{p}<0,01$ & $\mathrm{p}<0,01$ & $p<0,01$ & $p<0,01$ & 0,08 & $p<0,01$ & $\mathrm{p}<0,01$ & $\mathrm{p}<0,01$ & $\mathrm{p}<0,01$ \\
\hline$D-1$ & $\mathrm{p}<0,01$ & $\mathrm{p}<0,01$ & $\mathrm{p}<0,01$ & $\mathrm{p}<0,01$ & $p<0,01$ & $\mathrm{p}<0,01$ & $\mathrm{p}<0,01$ & $p<0,01$ & $\mathrm{p}<0,01$ & $\mathrm{p}<0,01$ & $p<0,05$ \\
\hline$E-F$ & 0,06 & $\mathrm{p}<0,05$ & $\mathrm{p}<0,05$ & $p<0,05$ & $p<0,05$ & 0,33 & $p<0,01$ & $p<0,01$ & $\mathrm{p}<0,01$ & $\mathrm{p}<0,01$ & $p<0,01$ \\
\hline$E-G$ & $\mathrm{p}<0,01$ & $p<0,01$ & $p<0,01$ & $p<0,01$ & $p<0,01$ & 0,61 & $\mathrm{p}<0,01$ & $p<0,01$ & 0,25 & 0,15 & 0,16 \\
\hline$E-H$ & $\mathrm{p}<0,01$ & $\mathrm{p}<0,01$ & $p<0,01$ & $\mathrm{p}<0,01$ & 0,07 & $p<0,01$ & $\mathrm{p}<0,01$ & $\mathrm{p}<0,01$ & 0,26 & 0,21 & 0,19 \\
\hline$E-I$ & $p<0,01$ & $\mathrm{p}<0,01$ & $\mathrm{p}<0,05$ & $p<0,05$ & 0,29 & 0,34 & 0,18 & $p<0,01$ & $\mathrm{p}<0,01$ & 0,31 & 0,13 \\
\hline$F-G$ & $p<0,01$ & 0,11 & $p<0,01$ & 0,44 & $p<0,01$ & 0,62 & $\mathrm{p}<0,01$ & $p<0,01$ & 0,52 & $\mathrm{p}<0,05$ & $p<0,05$ \\
\hline $\mathrm{F}-\mathrm{H}$ & $\mathrm{p}<0,01$ & $\mathrm{p}<0,01$ & $\mathrm{p}<0,01$ & $p<0,01$ & $p<0,01$ & $p<0,05$ & $\mathrm{p}<0,01$ & $p<0,01$ & 0,27 & $\mathrm{p}<0,01$ & $p<0,05$ \\
\hline$F-1$ & $p<0,05$ & $\mathrm{p}<0,01$ & $\mathrm{p}<0,01$ & $\mathrm{p}<0,01$ & $p<0,05$ & 0,36 & $\mathrm{p}<0,01$ & $p<0,01$ & $\mathrm{p}<0,01$ & $p<0,05$ & $p<0,05$ \\
\hline $\mathrm{G}-\mathrm{H}$ & 0,09 & $\mathrm{p}<0,01$ & $p<0,05$ & 0,32 & $p<0,05$ & $p<0,01$ & $p<0,01$ & $p<0,01$ & $p<0,01$ & 0,28 & 0,31 \\
\hline$G-I$ & 0,23 & 0,06 & $\mathrm{p}<0,01$ & 0,36 & $p<0,01$ & 0,68 & $\mathrm{p}<0,05$ & $\mathrm{p}<0,01$ & $\mathrm{p}<0,01$ & 0,13 & 0,18 \\
\hline $\mathrm{H}-\mathrm{I}$ & 0,25 & 0,51 & 0,65 & 0,62 & 0,11 & $\mathrm{p}<0,05$ & $p<0,05$ & $p<0,01$ & $p<0,01$ & 0,07 & 0,06 \\
\hline
\end{tabular}


Koeficijenti varijabilnosti za istraživana morfološka svojstva listova kreće u rasponu od 9,04 do 38,18 \%. Najnižu prosječnu vrijednost koeficijenta varijabilnosti imalo je svojstvo broj bočnih žila na lijevoj strani plojke (NVL), dok je najheterogenije svojstvo bila površina plojke (LA). Kao najheterogenije populacije izdvajaju se populacije Vlasina, Tresibaba i Đerdap (Tablica 1).

Rezultati provedene analize varijance (ANOVA) pokazuju da se stabla unutar populacija signifikantno razlikuju prema svim istraživanim svojstvima (Tablica 2). Populacije pokazuju statistički značajne razlike, na razini signifikantnosti 0,01 za sva promatrana morfološka svojstva listova (Tablica 2). U nastavku je provedeno i dodatno testiranje Fisherovim multiplim testovima (LSD) za sve parove populacija s ciljem utvrđivanja koje se točno populacije međusobno statistički značajno razlikuju (Tablica 3). Na temelju dobivenih rezultata može se zaključiti da se međusobno najviše razlikuju parovi populacija Vlasina i Boranja, zatim Boranja i Goč, Boranja i Đerdap (signifikantne razlike za sva promatrana svojstva), populacije Boranja i Lipovica (signifikantne razlike za sva promatrana svojstva osim LW25), Boranja i Fruška Gora (signifikantne razlike za sva promatrana svojstva osim LL/LW), Javor i Fruška Gora (signifikantne razlike za sva promatrana svojstva osim NT), kao i populacije Javor i Đerdap (signifikantne razlike za sva promatrana svojstva osima LL). Međusobno najsličnije su populacije Tresibaba i Javor (signifikantne razlike samo za svojstva PL i NT), potom populacije Fruška Gora i Đerdap (signifikantne razlike za svojstva LL; LL/LW; PL i NT).

U tablici 4 prikazan je udio pojedinih izvora varijabilnosti u ukupnoj varijanci za sva istraživana morfološka svojstva listova. Varijabilnost listova unutar stabla zauzima najveći udio od ukupne varijabilnosti, dok je međupopulacijska varijabilnost manja od unutarpopulacijske.

Iz dendrograma klasterske analize može se zaključiti, da su prema istraživanim morfološkim svojstima listova, među-

Tablica 4. Komponente varijance.

Table 4. Variance components.

\begin{tabular}{cccc} 
& \multicolumn{3}{c}{ Efekt - Effect (\%) } \\
\cline { 2 - 4 } Svojstvo / Trait & $\begin{array}{c}\text { Populacija } \\
\text { Population }\end{array}$ & $\begin{array}{c}\text { Stablo / populacija } \\
\text { Tree / population }\end{array}$ & $\begin{array}{c}\text { Unutar stabla } \\
\text { Within the tree }\end{array}$ \\
\hline LA & 3,47 & 25,11 & 71,42 \\
LPE & 6,74 & 31,62 & 61,64 \\
LW & 5,23 & 26,74 & 68,03 \\
LW25 & 13,78 & 36,75 & 49,47 \\
LW75 & 9,56 & 29,13 & 61,31 \\
LL & 18,45 & 31,22 & 50,33 \\
LL/LW & 18,42 & 26,15 & 55,43 \\
PL & 20,16 & 28,55 & 51,29 \\
NT & 8,44 & 18,26 & 73,30 \\
NVL & 4,46 & 29,15 & 66,39 \\
NVR & 15,54 & 23,17 & 61,29
\end{tabular}

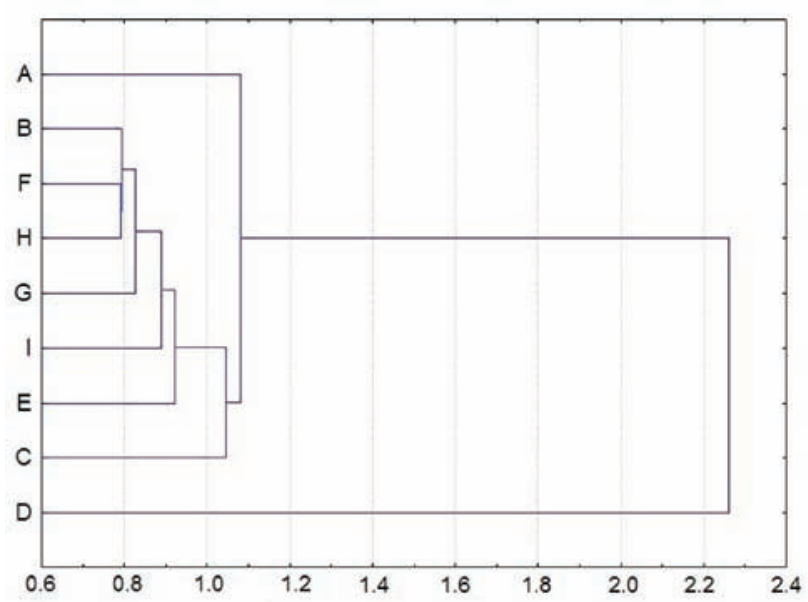

Slika 3. Dendrogram klaster analize baziran na Euklidskim udaljenostima Figure 3. The dendrogram of cluster analysis based on Euclidean distance

sobno najsličnije populacije Tresibaba, Javor i Fruška Gora (povezuju se na najmanjoj udaljenosti). Najjužnija populacija Vlasina i najzapadnija populacija Boranja su morfološki najrazličitije. Populacija Boranja se nalazi na značajno većoj udaljenosti u odnosu na ostalih osam populacija (Slika 3).

\section{RASPRAVA I ZAKLJUČCI DISCUSSION AND CONCLUSIONS}

Dobiveni rezultati u ovom istraživanju potvrdili su postojanje značajne varijabilnosti morfoloških svojstava listova i ukazuju na visoku fenotipsku varijabilnost istraživanih svojstava u populacijama divlje trešnje u Srbiji. Na temelju dobivenih rezultata po provedenoj statističkoj analizi promatranih morfoloških svojstava listova divlje trešnje, može se zaključiti da je najvarijabilnije svojstvo površina plojke (LA). Prosječna vrijednost duljine plojke $(\mathrm{LL}=92,71 \mathrm{~mm})$ je približna prosječnim vrijednostima za populacije divlje trešnje u Bosni i Hercegovini ( $\mathrm{LL}=86,34 \mathrm{~mm}$ ), Švicarskoj ( $\mathrm{LL}=$ 89,16 mm), Hrvatskoj ( $\mathrm{LL}=91,93 \mathrm{~mm}$ ), Sloveniji ( $\mathrm{LL}=89,09$ $\mathrm{mm}$ ) i istočnoj Srbiji ( $\mathrm{LL}=95,18 \mathrm{~mm}$ ) (Mikić 2007). Prosječne vrijednosti širine plojke $(\mathrm{LW}=52,70 \mathrm{~mm})$ i duljine peteljke $(\mathrm{PL}=28,24 \mathrm{~mm})$ su također približne prosječnim vrijednostima u populacijama u Bosni i Hercegovini ( $\mathrm{LW}=$ 49,65 mm; PL = 28,03 mm), Švicarskoj ( $\mathrm{LW}=48,84 \mathrm{~mm}$; PL $=30,36 \mathrm{~mm})$, Hrvatskoj $(\mathrm{LW}=45,91 \mathrm{~mm} ; \mathrm{PL}=28,24 \mathrm{~mm})$, Sloveniji ( $\mathrm{LW}=46,91 \mathrm{~mm} ; \mathrm{PL}=28,27 \mathrm{~mm}$ ) $\mathrm{i}$ istočnoj Srbiji ( $\mathrm{LW}=49,50 \mathrm{~mm} ; \mathrm{PL}=31,22 \mathrm{~mm}$ ) (Mikić 2007). Populacije divlje trešnje s područja centralne Srbije imaju prosječne vrijednosti površine plojke $32,6 \mathrm{~cm}^{2}$, širine plojke $5,2 \mathrm{~cm}$, dužine plojke 9,8 cm i odnos duljine i širine plojke 1,89 (Rakonjac i sur. 2014). Trešnja s područja Bavarske ima plojku duljine 6-15 cm i širine oko $3 \mathrm{~cm}$ (Krüssman 1978). Plojka divlje trešnje sa šireg područja Srbije je oko $10 \mathrm{~cm}$ duga i oko $5 \mathrm{~cm}$ široka (Jovanović 1972). Duljina plojke na 23 stabla divlje trešnje iz Kraljevačke regije se kreće od 8,8 do $11,9 \mathrm{~cm}$, 
a širina od 4,3 do 6,3 cm (Rakonjac 1993). Na proučavanim genotipovima divlje trešnje s Golije utvrđeno ja da se duljina plojke kreće u intervalu od $4-10 \mathrm{~cm}$, a širina plojke varira od 4-6 cm (Jovković 1999). U 22 populacije divlje trešnje iz Bosne i Hercegovine utvrđene su prosječne vrijednosti duljine plojke $80,03 \mathrm{~cm}$, širine plojke $42,94 \mathrm{~cm}$ i duljine peteljke $29,51 \mathrm{~cm}$ (Ballian i sur. 2012). Najveće prosječne vrijednosti odnos duljine i širine plojke izmjerene su kod populacija Vlasina $(\mathrm{LL} / \mathrm{LW}=2,05)$ i Javor $(\mathrm{LL} / \mathrm{LW}=1,87)$ koje se nalaze na najvećoj nadmorskoj visini (iznad $1100 \mathrm{~m}$ ). Povećanje odnosa duljine i širine plojke s porastom nadmorske visine utvrđeno je u populacijama divlje trešnje u Bosni i Hercegovini (Mikić 2007; Ballian i sur. 2012) i na području centralne Srbije (Rakonjac i sur. 2014).

Provedena analiza varijance (ANOVA) potvrdila je postojanje statistički značajnih razlika između vrijednosti aritmetičkih sredina istraživanih svojstava i na međupopulacijskoj i na unutarpopulacijskoj razini. Populacije su se najviše razlikovale za svojstvo dužina peteljke (PL), a najmanje razlike uočene su kod svojstva duljina plojke (LL).

Unutarpopulacijska varijabilnost veća je od međupopulacijske varijabilnosti, što je i očekivano. To je potvrđeno pravilo $\mathrm{u}$ provedenim studijama morfološke varijabilnosti listova Quercus robur L. (Franjić 1996), Betula pendula Roth. (Kajba 1996), Quercus pubescens Willd. (Škvorc i sur. 2005), Sorbus torminalis /L./ Crantz (Idžojtić i sur. 2006), Ulmus minor Mill. (Zebec i sur. 2010; Zebec i sur. 2014), Quercus trojana Webb. (Ballian i sur. 2014), Alnus incana /L./ Moench i A. glutinosa /L./ Gaertn. (Poljak i sur. 2014), Populus nigra L. (Čortan i sur. 2015).

Provedenom klasterskom analizom nije utvrđena prisutnost geografske povezanosti i izdiferenciranosti istraživanih populacija. Populacije se nasumično grupiraju i njihov raspored je uslovljen u mikroekološkim uvjetima staništa. Populacija Vlasina se izdvaja s najvećom prosječnom vrijednošću odnosa duljine i širine plojke, a polulacija Boranja se izdvaja s najvećim prosječnim vrijednostima mjerenih varijabli. Nasumičan raspored i nepostojanje geografske izdiferenciranosti uočeno je kod Juniperus excelsa M. Bieb. (Mazur i sur. 2004), Juniperus oxycedrus L. (Brus i sur. 2011), Alnus incana /L./ Moench (Krauze-Michalska i Boratynska 2013), Quercus trojana Webb. (Ballian 2014), Prunus avium L. (Rakonjac i sur. 2014). Nasuprot ovomu, postojanje geografske izdiferenciranosti utvrđeno je kod populacija Sorbus domestica L. na području Balkanskog poluotoka (Brus i sur. 2011) i na području Hrvatske (Poljak i sur. 2015), kod populacija Sorbus torminalis /L./ Crantz u kontinentalnom dijelu Hrvatske (Idžojtić i sur. 2006), te kod Ulmus minor Mill. na području hrvatske Podravine (Zebec i sur. 2010). Odsutnost geografske izdiferenciranosti kod divlje trešnje može se objasniti time, što je ovo stranooplodna vrsta karakterizirana visokim stupnjem heterozigotnosti, te se na istom lokalitetu mogu naći različiti genotipovi
(Rakonjac i sur. 2014). Također rana povijesna fragmentacija ishodišnih populacija koje su vremenom adaptirale na uvjete staništa, može utjecati na nepostojanje geografske izdiferenciranosti (Schirone i Spada 2000).

Na temelju dobivenih rezultata može se zaključiti de se raspoloživi genofond divlje trešnje u Srbiji odlikuje zadovoljavajućim stupnjem genetičke varijabilnosti, te predstavlja dobru polaznu osnovu za proces daljnjeg oplemenjivanja. Značajan biodiverzitet između deset genotipova divlje trešanje (Prunus avium L.) porijeklom iz jugoistočne Srbije utvrđen je ispitivanjem fenoloških, morfološkkih i kemijskih osobina. Razina genetičkog diverziteta vrlo je visoka te se istraživana populacija može koristiti u budućim oplemenjiačkim programima (Mratinić i sur. 2012). Velika varijabilnost kavlitativnih i kvantitativnih svojstava listova i plodova populacija divlje trešnje s područja centralne Srbije potvrđuju značajnu genetičku raznolikost te ukazuju na bogatstvo genofonda (Rakonjaci i sur. 2014). U cilju dugoročnog očuvanja i unapređenja ekološke adaptabilnosti i evolutivnog potencijala populacija divlje trešnje u Srbiji potrebno je započeti provedbu adekvatnih mjera in situ i ex situ konzervacije.

Istraživanja varijabilnosti divlje trešnje u BiH vršena na morfološkim karakteristikama sjemena, ukazuju na veliku unutarpopulacijsku varijabilnost. Stabla kod kojih su utvrđene minimalne veličine istraživanih svojstva pretstavljaju ,divlji tip“ divlje trešnje, poznat kao varijatet Prunus avium var. actiana L. Sjeme većih dimenzija dolazi sa stabala koja su nastala hibridizacijom divlje trešnje i domaćih sorti trešnje (Ballian, 2000). Nasuprot visokoj varijabilnosti istraživanih morfoloških svojstava, u istraživanjima mikrosatelitne DNK varijabilnost populacija divlje trešnje (Prunus avium L.) iz središnje Bosne registrirana je relativno mala genetička varijabilnost. Između populacija divlje i pitome trešnje (cv. „Alica") ne postoji velika razlika u strukturi mikrosatelitske DNK (Ballian, 2004).

Na temelju obavljenih istraživanja može se zaključiti da je u istraživanim populacijama divlje trešnje utvrđena visoka stopa varijabilnosti istraživanih morfoloških svojstava listova. Dobiveni rezultati su osnova za nastavak istraživanja koja je neophodno provesti u cilju davanja smjernica i preporuka za očuvanje i usmjereno korištenje genetskih resursa divlje trešnje na području Srbiji i jugoistočne Europe. Za potpunije upoznavanje varijabilnosti divlje trešnje u dijelu prirodnog areala, istraživanja treba proširiti uporabom molekularnih markera.

\section{LITERATURA}

\section{REFERENCES}

- Aradhya, M. K., C. Weeks, Ch. J. Simon, 2004: Molecular characterization of variability and relationships among seven cultivated and selected wild species of Prunus L. using amplified fragment length polymorphism, Sci. Hortic., 103: 131-144. 
- Ballian, D., 2000: Početna istraživanja varijabilnosti morfoloških svojstava sjemena divlje trešnje (Prunus avium L.), Sumar. list, 124 (5-6): 271-278.

- Ballian, D., 2004: Varijabilnost mikrosatelitne DNK u populacijama divlje trešnje (Prunus avium L.) iz središnje Bosne, Sumar. list, 128 (11-12): 649-653.

- Ballian, D., A. Čabaravdić, 2007: Neki korelacijski odnosi između svojstava pupova, cvijeta i sjemena divlje trešnje (Prunus avium L.) iz populacije Mrkovići, Works of the Faculty of Forestry University of Sarajevo, 1: 29 - 38.

- Ballian, D., A. Hajrudinović, J. Franjić, F. Bogunić, 2014: Morfološka varijabilnost lista makedonskoga hrasta (Quercus trojana Webb.) u Bosni i Hercegovini i Crnoj Gori, Sumar. list, 138 (3-4): 135-144.

- Ballian, D., F. Bogunić, A. Čabaravdić, S. Pekeč, J. Franjić, 2012: Population differentiation in the wild cherry (Prunus avium L.) in Bosnia and Herzegovina, Period. Boil., 114 (1): 43-54.

- Banković, S., M. Medarević, D. Pantić, N. Petrović, B. Šljukić, S. Obradović, 2009: Šumski fond Republike Srbije - stanje i problemi, Glasnik Šumarskog fakulteta, 100: 7-30.

- Brus, R., D. Ballian, P. Zhelev, M. Pandža, M. Bobinac, J. Acevski, Y. Raftoyannis, K. Jarni, 2011: Absence of geographical structure of morphological variation in Juniperus oxycedrus L. subsp. oxycedrus in the Balkan Peninsula, Eur. J. For. Res., 130: 657-670.

- Brus, R., D. Ballian, F. Bogunić, M. Bobinac, M. Idžojtić, 2011: Leaflet morphometric variation of service tree (Sorbus domestica L.) in the Balkan Peninsula, Plant Biosyst., 145 (2): 278-285.

- Bejdl, R., (1954): Prunus avium, the tree of the future (Tresen cilova drevina blizke buducnosti), Lesen, Prace 33 (8): 354-357.

- Bylesjö M., V. Segura, R.Y. Soolanayakanahally, A. M. Rae, J. Trygg, P. Gustafsson, S. Jansson, N.R. Street, 2008: LAMINA: a tool for rapid quantifi cation of leaf size and shape parameters, BMC Plant Biol. ogy. DOI: 10.1186/1471-2229-8-82.

- Boritzki, M., J. Plieske, D. Struss, 2000: Cultivar identification in sweet cherry (Prunus avium L.) using AFLP and microsatellite markers, Acta Hort., 538: 505-510.

- Čortan, D., B. Tubić, M. Šijačić-Nikolić, D. Borota, 2015: Variability of Black poplar (Populus nigra L.) leaf morphology in Vojvodina, Serbia, Sumar. list, 139 (5-6): 245-252.

- Ducci, F., F. Santi, 1997: The distribution of clones in managed and unmanaged populations of wild cherry (Prunus avium L.), Can. J. For. Res., 27: 1998-2004.

- Ducci, F., 2005: Monografia sul ciliegio selvatico Prunus avium L. CRA - Instituto Sperimentale per di Selvicoltura di Arezzo - Italia: 126.

- Ducci, F., F. Santi, 2004: The distribution of clones in managed and unmanaged populations of wild cherry (Prunus avium L.), Can. J. For. Res., 27:1998-2004.

- Franjić, J., 1996: Morfometrijska analiza varijabilnosti lista posavskih i podravskih populacija hrasta lužnjaka (Quercus robur L., Fagaceae) u Hrvatskoj, Glasn. Šum. pokuse, 33: 153-214.

- Gerlach, H. K., R. Stosser, 1998: Sweet cherry cultivar identification using RAPD-derived DNA fingerprints, Acta Hort., 468: 63-69

- Guarino, C., S. Santoro, L. De Simone, G. Cipriani, 2009: Source Prunus avium: nuclear DNA study in wild populations and sweet cherry cultivars, Genome 52: 320-337.

- Idžojtić, M., M. Zebec, D. Drvodelić, 2006: Varijabilnost populacija brekinje u kontinentalnom dijelu Hrvatske prema morfološkim obilježjima lišća i plodova, Glas. šum. pokuse, pos. izd. 5: 305-314.

- Jing- Yong, Z., L. Xiu-Lan, L. Ren-Dao, C. Hong-Qiang, 2009: Relationship of Sweet Chery (Prunus avium L.) Based on SSR Markers, Plant Sci. Res., 2 (1): 6-10.

- Jovanović, B., 1972: Prunus L. in M. Josifović (ed): Flora Srbije, IV: 198.

- Jovković, R., 1999: Potencijalna vrednost trešnje vrapčare (Prunus avium L.) u proizvodnji biološko visoko vredne hrane, Magistraska teza, Šumarski fakultet, Beograd.

- Kajba, D., 1996: Međupopulacijska i unutarpopulacijska varijabilnost breze (Betula pendula Roth.) u dijelu prirodne rasprostranjenosti u Republici Hrvatskoj, Glas. Šum. Pokuse, 33: 53-108.

- Kitin, P., I. Iliev, A. Scaltsoyiannes, C. Nellas, A. Rubos, R. Funada, 2005: Acomparative histological study between normal and fascinated shoots of Prunus avium generated in vitro, Plant Cell, Tissue and Organ Culture, 82: 141-150.

- Kleinschmit, J., R. Stephan, I. Wagner, 2003: European Forest Genetic resources Programme: Wild Fruit Trees Genetic Resources Conservation Strategy. http://www.ipgri.cgiar.org/networks/euforgen/networks/

- Kleinschmit, J., B. R. Stephan, F. Ducci, P. Rotach, C. Matyas, 1999: Inventoriesof Noble Hardwoods genetic resources: basic requirements in Noble Hardwoods Network. Report of the Third Meeting, 13-16 June 1998, Sagadi, Estonia. IPGRI (9297).

- Krauze-Michalska, E., K. Boratynska, 2013: European geography of Alnus incana leaf variation, Plant Biosyst., 147: 601-610.

- Krüssman, G., 1978: Handbuch der Laubghözle. Berlin und Hamburg, Bd I-II.

- Mazur, M., K. Boratynska, K. Marcysiak, Y. Didukh, A. Romo, P. Kosinski, A. Boratynski, 2004: Low level of inter-populational diff erentiation in Juniperus excelsa M. Bieb. (Cupressaceae), Dendrobiology, 52: 39-46.

- Meier-Dinkel, A., J. Svolba, J. Kleinschmit, 1997: Selektierte, mikrovermehrte Vogelkirschen - Klone. AFZ - Der Wald, Allgemeine Forst Zeitschrift fur Waldwirtschaft und Umweltvorsorge, 52: 963-964.

- Mikić, T., 2007: Analiza morfoloških parametara lista divlje trešnje (Prunus avium L.) u Bosni i Hercegovini, Disertacija, Šumarski fakultet u Banja Luci.

- Mikić, T., D. Ballian, S. Orlović, 2004: Varijabilnost plodova i semena divlje trešnje (Prunus avium L.) sa područja Bosne i Hercegovine, III Kongres genetičara Srbije, Zbornik radova, Subotica: 145.

- Mratinić, E., M. Fotirić Akšić, R. Jovković, 2012: Analysis of wild sweet cherry (Prunus avium L.) germplasm diversity in South-East Serbia, Genetika 44 (2): 259-268.

- Nonić, M., V. Popović, I. Kerkez, M. Šjiačić-Nikolić, 2013: Varijabilnost morfometrijskih karakteristika semena različitih test stabala divlje trešnje (Prunus avium L.) sa područja Beograda, Šumarstvo, 65 (1-2), 113-123.

- Poljak, I., M. Idžojtić, I. Sapić, J. Vukelić, M. Zebec, 2014: Varijabilnost populacija bijele (Alnus incana /L./ Moench) i crne johe (A. glutinosa /L./ Gaertn.) na području Mure i Drave prema morfološkim obilježjima listova, Sumar. list, 138 (1-2): 7-17.

- Poljak, I., D. Kajba, I. Ljubić, M. Idžojtić, 2015: Morphological variability of leaves of Sorbus domestica L. in Croatia, Acta Soc. Bot. Pol., 84(2): 249-259. 
- Rakonjac, V., 1993: Genetička varijabilnost populacije trešnje (Prunus avium L.) Kraljevačkog regiona, Magistraska teza, Poljoprivredni fakultet, Beograd.

- Rakonjac, V., E. Mratinić, R. Jovković, M. Fotirić Akšić, 2014: Analysis of Morphological Variability in Wild Cherry (Prunus avium L.) Genetic Resources from Central Serbia, J. Agr. Sci. Tech., 16: 151-162.

- Russell, K., 2003: EUFORGEN Technical guidelines for genetic conservation and use for wild cherry (Prunus avium). International Plant Genetic Resources Institute, Rome, Italy. p. 6.

- Santi, F., M. Lemoine, 1990: Genetic markers for Prunus avium L. 2. Clonal identifications and discrimination from P. cerasus and P. cerasus P. avium, Ann. Sci. For., 47: 219-227.

- Santi, F., H. Muranty, J. Dufour, L.E. Paques, 1998: Genetic parametersand selection in a multisite Wild cherry clonal test, Silvae Genet., 47: 61-67.

- Schirone, B., F. Spada, 2000: Some remarks on the conservation of genetic resources of Mediterranean oaks. U: S. Borelli, M. C. Varela (ur.): Mediterranean Oaks Network, Report of the first meeting, 21-26, Antalya.

- StatSoft Inc., 2004. STATISTICA, version 7.

- Šijačić-Nikolić, M., J. Milovanović, 2012: Conservation and sustainable use of forest genetic resources throught an example of watland ecosystems, Agriculture and Forestry, 57 (1): 23-31.
- Škvorc, Ž., J. Franjić, M. Idžojtić, 2005: Population structure of Quercus pubescens Willd. (Fagaceae) in Croatia according to morphology of leaves, Acta Bot. Hung., 47(1-2): 193-206.

- Tančeva Crmarić, O., S. Štambuk, Z. Šatović, D. Kajba 2006: Genotipska raznolikost divlje trešnje (Prunus avium L.) u dijelu prirodne rasprostranjenosti u Hrvatskoj, Sumar. list, 130 (1112): 543-555.

- Tucović A. (1965): Sistematika i bioekološka istraživanja crne topole (Populus nigra L.) u Srbiji, Disertacija, Univerzitet u Beogradu, Šumarski fakultet, Beograd.

- Turkec, A., M. Sayar, B. Heinze, 2005: Identification of sweet cherry cultivars (Prunus avium L.) and analysis of their genetic relationships by chloroplast sequence-characterised amplified re- gions (cpSCAR), Genet. Resour. Crop Ev., 53: 1635-1641.

- Zebec, M., M. Idžojtić, I. Poljak, 2014: Morfološka varijabilnost nizinskog brijesta (Ulmus minor Mill. sensu latissimo) na području kontinentalne Hrvatske, Sumar. list, 138 (11-12): 563572.

- Zebec, M., M. Idžojtić, I. Poljak, I. Mihaldinec, 2010: Varijabilnost nizinskog brijesta (Ulmus minor Mill. sensu latissimo) na području hrvatske Podravine prema morfološkim svojstvima listova, Sumar. list, 134 (11-12): 569-580.

- Weiser, F. 1996: Ergebnisse einer 33 jahrigen Einzelbaum-Nachkommenschaftsprufung nach freiem Abbluhen von Vogelkirsche, Prunus avium L. var. avium. Silvae Genet., 45: 260-266.

\section{Summary}

Wild cherry (Prunus avium L.) is the most important European tree species in the family Rosaceae (Russell 2003). It is very valuable forest species that grows in mixed forests in Southern, Central and Western Europe. In the growing stock of Serbia wild cherry falls into the category of species at risk (Banković et al. 2009) to which is not paid enough attention. The researches of population structure and genetic variability at the level of genotypes and/or populations are the basis for the knowledge on the adaptive and genetic potential of wild cherry in some area.

The morphological variability of leaves in nine natural populations of wild cherry (Prunus avium L.) in Serbia was studied in this paper. The research material was collected in nine natural populations of wild cherry in Serbia (Figure 1, Slika 1). The leaves from ten trees per population were collected while every tree was presented with 50 healthy and intact leaves. The leaves were collected from borderline trees or trees located in an isolated position usually from the southern exposed part of the crown, from its outer well-lit part. Leaf morphological characteristics were described by descriptive statistical indicators: arithmetic mean (x), standard deviation (SD), coefficient of variation (CV). In order to determine the intra-population and inter-population variability the univariate analysis of variance (ANOVA) was performed.

Results obtained by performed statistical analysis of studied morphological characteristics of wild cherry leaves showed that the most variable characteristic is the leaf surface area (LA). The analysis of variance (ANOVA) confirmed presence of statistically significant differences between values of the arithmetic means of the studied characteristics on both inter- and intra-population level. Populations varied the most in the petiole length (PL) and the smallest differences were observed in the leaf length (LL). Intra-population variability is greater than inter-population variability.

Based on the conducted researches it can be concluded that in the studied wild cherry populations a high rate of variability of the studied leaf morphological characteristics was determined. The obtained results are the basis for the continuation of the research that needs to be conducted in order to provide guidelines and recommendations for the conservation and targeted use of genetic resources of this species in Serbia and beyond. For a complete knowledge on the variability of wild cherry in a part of the natural area the research should be expanded by the use of molecular markers.

KEY WORDS: Prunus avium L., leaf morphology, variability, population. 
Hrvatska komora inženjera šumarstva i drvne tehnologije (Croatian Chamber of Forestry and Wood Technology Engineers) osnovana je na temelju Zakona o Hrvatskoj komori inženjera šumarstva i drvne tehnologije (NN 22/06).

Komora je samostalna i neovisna strukovna organizacija koja obavlja povjerene joj javne ovlasti, čuva ugled, čast i prava svojih članova, skrbi da ovlašteni inženjeri obavljaju svoje poslove savjesno i u skladu sa zakonom te promiče, zastupa i usklađuje njihove interese pred državnim i drugim tijelima u zemlji i inozemstvu.

Članovi Komore:

- inženjeri šumarstva i drvne tehnologije koji obavljaju stručne poslove iz područja šumarstva, lovstva i drvne tehnologije.

\section{Stručni poslovi (Zakon o HKIŠDT, članak 1):}

- projektiranje, izrada, procjena, izvođenje i nadzor radova iz područja uzgajanja, uređivanja, iskorištavanja i otvaranja šuma, lovstva, zaštite šuma, hortikulture, rasadničarske proizvodnje, savjetovanja, ispitivanja kvalitete proizvoda, sudskoga vještačenja, izrade i revizije stručnih studija i planova, kontrola projekata i stručne dokumentacije, izgradnja uređaja, izbor opreme, objekata, procesa i sustava, stručno osposobljavanje i licenciranje radova u šumarstvu, lovstvu i preradi drva.

\section{Javne ovlasti Komore:}

- vodi imenik ovlaštenih inženjera šumarstva i drvne tehnologije,

- daje, obnavlja i oduzima licencije (odobrenja) pravnim i fizičkim osobama za obavljanje radova iz područja šumarstva, lovstva i drvne tehnologije,

- utvrđuje profesionalne obveze članova i njihovo obavljanje u skladu s kodeksom strukovne etike,

- provodi stručne ispite za ovlaštene inženjere,

- drugi poslovi koji su utvrđeni kao javne ovlasti.

Akti koje Komora izdaje u obavljanju javnih ovlasti, javne su isprave.

Ostali poslovi koje obavlja Komora:

- promiče razvoj struke i skrbi o stručnom usavršavanju članova,

- potiče donošenje propisa kojima se utvrđuju javne ovlasti Komore u skladu s kriterijima europske i svjetske prakse,

- zastupa interese svojih članova,

- daje stručna mišljenja kod pripreme propisa iz područja šumarstva, lovstva i drvne tehnologije,

- organizira stručno usavršavanje svojih članova,

- izdaje glasilo Komore te druge stručne publikacije.

Članovima Komore izdaje se rješenje, pečat $i$ iskaznica ovlaštenoga inženjera. Za uspješno obavljanje zadataka te postizanje ciljeva ravnopravnoga i jednakovrijednoga zastupanja struka udruženih u Komoru, članovi Komore organizirani su u strukovne razrede:

- Razred inženjera šumarstva,

- Razred inženjera drvne tehnologije.

Članovi Komore imaju odgovornosti u obavljanju stručnih poslova sukladno zakonskim i podzakonskim aktima te Kodeksu strukovne etike. 